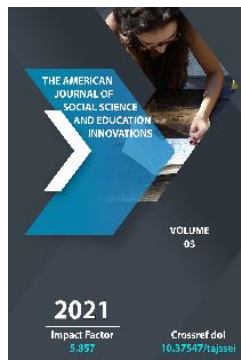

\title{
The System Of Training And Development Of Field Practice In Biology
}

\author{
Mansurbek Bayrambekovich Ongarov \\ Senior Teacher, Department Of "Zoology And Anatomy", Tashkent State Pedagogical \\ University Named After Nizami, Uzbekistan
}

Copyright: Original

content from this work may be used under the terms of the creative commons attributes 4.0 licence.

\section{ABSTRACT}

This article describes the system of field practice, the place of field practice; the content of the methods studied during the field trips is described. During the internship, students were also given the skills to capture and anesthetize invertebrates found in the aquatic environment and on land, and to use them in the evening classes of the internship.

\section{KEYWORDS}

Practice, excursion, mountain, desert, experiment, river, animals, insects, observation, comparison.

\section{INTRODUCTION}

Description of the field practice. Before conducting an internship, it is important to consider the location of the internship. When practicing on large rivers, more time is spent studying aquatic animals, and we need to know exactly why birds choose to build their nests near rivers. [1] It is also important that the mountain and desert areas are rich in flora and fauna, which are radically different from each other.

Depending on the location of the internship, field trips and their location may also change. The tutor organizes a variety of field trips during the field trip. Before the start of the tour, students are explained by the teacher the 
purpose, tasks, procedures, safety rules, how to participate [5].

\section{THE MAIN FINDINGS AND RESULTS}

Students involved in field practice need to make effective use of the methods used during the internship, and high results can be achieved if the methods are used appropriately and effectively. The following methods are used during the practice.

Observation method. In field practice, this method helps to describe the growth, development, reproduction, interaction of living organisms in nature with the environment and other biological phenomena. This method helps students to identify the characteristics of insects by observing them directly during the tour.

Method of comparison. This method explores the laws that are common to all living organisms in different field organisms (e.g., between species, different systematic groups) in field practice. An effective aspect of this method infield practice is that it helps students analyze the adaptation of invertebrates to their habitats, as well as the origin and evolution of various organisms, in evening classes.

Experiment, an experimental method. In the field practice, this method is carried out using reference books that students collect on each field trip during evening classes. It also involves an in-depth study of the properties of biological objects and processes. The difference between the experimental method and the above methods is that it is aimed at the active study of the object under study.

Demonstration methods. The use of visual methods in the field practice, emotional perception of objects and events based on the content of the training material; allows you to compare them, identify their features, generalize, synthesize, draw conclusions. The use of this method in practice is combined with verbal, practical, logical, problem-based methods.

The advantages of using this method in the field during training are as follows.

Ability to develop students 'visual thinking, activate students' cognitive activity, master the methods of mental activity, observe biological objects, conduct experiments on them, apply theoretical knowledge in practice, identify and classify the studied phenomena on the basis of diagrams, tables will give.

Method of recognition and identification of natural objects. This method is one of the most important in the teaching of biology, because in botany, plant organs, plant species, species, families, classes are determined. To do this, of course, during the internship, students must be prepared and use a sufficient number of handouts and didactic materials, herbarium sets.

During the internship, in the evening classes in zoology, the organs of animals, along with knowing their functions, determine which type, class, genus, family the animals belong to. The effectiveness of this method requires the availability of didactic and distribution materials, such as drugs, models, complexes, prepared from animals and their organs, reflecting the diversity of the animal world [14].

Story method. It consists of figurative and coherent description of lesson methods. During practice, this method is used to describe the structure and life of animals by 
telling stories about animal life that the supervisor has seen, heard, and read about.

During the field practice, the storytelling method is not used in its pure form, but in combination with other methods: conversation, demonstration, problemsolving, and demonstration, practical and other methods. The effectiveness of the storytelling method depends on the teacher's ability to choose the right topic and problem. For example, in the study of reptiles, we can discuss with students how their appearance differs from that of aquatic and terrestrial animals.

The storytelling method requires the teacher to be fluent in speech, to pronounce words correctly in literary language, and to express ideas concisely and clearly. Parts of the story may be illustrated or enriched with examples from the scientific literature. For example, the French writer Jules Verne's "Children of Captain Grant" explains the spread of the sleeping sickness virus through the mosquitoes and that the mosquitoes are found only in tropical Africa.

Problem research method. Teaching students to create problem situations on the topics of excursions, to create a chain of problem questions, to create problem assignments as well as to conduct experiments, to teach students to think rationally about problematic situations, to think logically, to conduct research experiments, to generalize.

Improving the quality of teaching biology in higher education, as well as in field practice, leads to individual changes in students in each course. Therefore, the teacher must have a thorough knowledge of the subject at each stage of his / her work, the subject and each of its sections.

In field practice, the delivery of science information to students consists of three main parts.

- Achieving learning objectives, ie mastering the basics of biology, as well as independent work in the field, the implementation of independent educational tasks.

- Solve problems in order to apply the basic theoretical knowledge of biology in practice, perform tasks in accordance with the established instructions.

- Apply theoretical knowledge in practice, analyze the results and draw conclusions.

These three phases of teaching primarily develop students' ability to work independently, and their ability to use them effectively in a variety of contexts increases their effectiveness.

The following table describes the skills used in the field practice.

Table 1

\begin{tabular}{|l|l|}
\hline $\begin{array}{c}\text { O'quv dala amaliyotida bajariladigan } \\
\text { ko'nikmalar turlari }\end{array}$ & \multicolumn{1}{|c|}{$\begin{array}{c}\text { O'quv dala amaliyotida talabalar tomonidan } \\
\text { ko'nikmalarning bajarilishi }\end{array}$} \\
\hline Field practice skills & $\begin{array}{l}\text { Preparation of micropreparations, work with } \\
\text { magnifying devices, efficient use of microscopes, self- } \\
\text { preparation of equipment for field practice (sachok, } \\
\text { marelka, etc.) }\end{array}$ \\
\hline
\end{tabular}




\begin{tabular}{|l|l|}
\hline $\begin{array}{l}\text { Skills to create herbariums from plants } \\
\text { and collections from insects during } \\
\text { fieldwork. }\end{array}$ & $\begin{array}{l}\text { The struggle for survival in plants and insects, the } \\
\text { observation of adaptation in the natural selection of } \\
\text { adaptations, and on this basis the preparation of } \\
\text { herbariums and collections for each plant and animal } \\
\text { species and their registration in accordance with the } \\
\text { requirements of the training program They learn. }\end{array}$ \\
\hline $\begin{array}{l}\text { Ability to observe and experiment with } \\
\text { plants and animals during fieldwork. }\end{array}$ & $\begin{array}{l}\text { Conduct and analyze experiments on the struggle for } \\
\text { survival of plants and animals, the laws of natural } \\
\text { selection and heredity. }\end{array}$ \\
\hline Plant and animal recognition skills in field \\
trips planned for each topic. & $\begin{array}{l}\text { The facilitator attached to the general group should give } \\
\text { small groups specific assignments on a topic included in } \\
\text { the field practice programand study them in the evening } \\
\text { classes using plant and animal identification books. }\end{array}$ \\
\hline Learning skills developed in students field practice. & $\begin{array}{l}\text { Independently master the topics given in the textbooks } \\
\text { and additional literature, summarize and compare them } \\
\text { independently during the internship, as well as draw } \\
\text { conclusions based on the picture table, express their } \\
\text { views briefly and concisely, independently on the } \\
\text { educational material, work, formalize the acquired } \\
\text { knowledge at the end of the field practice in the form of } \\
\text { independent work and report to the supervising } \\
\text { teacher. }\end{array}$ \\
\hline
\end{tabular}

During the fieldwork, students will explore the range of invertebrates, depending on the habitat, during field trips.

When collecting aquatic animals, the water traps and beetles that float on the surface of the water are first collected in a water net bag and placed in appropriate containers. Invertebrates that live in the aquifer are then collected with a net bag, while those that live in the water are collected with shovels.
The leeches of leeches, mollusks, and insects that cling to algae are carefully separated from the grass and placed in buckets of water. Some of the collected material will be brought to the camp for live observation.

Several water bodies have been studied and invertebrates live in them

Based on the following table, it is possible to determine the occurrence of invertebrates, such as scorpions, amphibians, and beetles, in the water basin selected for the experiment.

You can do this by spreading invertebrates in water bodies.

Table 2

\begin{tabular}{|c|c|c|c|c|c|}
\hline $\begin{array}{c}\text { The name of the } \\
\text { animal }\end{array}$ & Spring water & Pool water & $\begin{array}{c}\text { Stream } \\
\text { water }\end{array}$ & River water & Total \\
\hline Water scorpion & & & & & \\
\hline Water bag & & & & & \\
\hline
\end{tabular}


The American Journal of Social Science and Education Innovations (ISSN - 2689-100x)

Published: March 25, 2021 | Pages: 171-177

Doi: https://doi.org/10.37547/tajssei/Volume03Issue03-23

\begin{tabular}{|c|l|l|l|l|l|}
\hline The water beetle & & & & & \\
\hline Total & & & & & \\
\hline
\end{tabular}

You need to keep in mind that the name of the selected location will change during each field operation.

The following table shows the occurrence of invertebrates, such as earthworms, beetle larvae, and amphibians, in the area selected for the experiment. You can do this as follows.

Table 3

\begin{tabular}{|c|c|c|c|c|c|c|}
\hline Animal name & $\begin{array}{c}\text { The place } \\
\text { taken for the } \\
\text { sample }\end{array}$ & $10 \mathrm{~cm}$ deep & $\begin{array}{c}\text { Depth of 10- } \\
20 \mathrm{~cm}\end{array}$ & $\begin{array}{c}\text { Depth of } \\
20-30 \mathrm{~cm}\end{array}$ & $\begin{array}{c}\text { Depth of } \\
30-40 \mathrm{~cm}\end{array}$ & Total \\
\hline $\begin{array}{c}\text { The } \\
\text { earthworm }\end{array}$ & & & & & & \\
\hline Beetle larvae & & & & & & \\
\hline Multi-legged & & & & & & \\
\hline Total & & & & & & \\
\hline
\end{tabular}

You need to keep in mind that the name of the selected location will change during each field operation.

\section{CONCLUSION}

In conclusion, it should be noted that at a time when modern science is gaining momentum, students need to use effective methods and tools in the educational process. When conducting field practice in biology in pedagogical higher education institutions, first of all, it is necessary to strengthen the scientific relationship between the teacher and the student, that is, to know the level of practical application of theoretical knowledge acquired by students during their studies. First of all, it is necessary to establish cooperation between the teacher and the student, that is, to improve the learning activities of students, to strengthen and harmonize their attitude to practice, as well as to organize them in harmony.

Enhancing students' interest in biology and meeting their need for knowledge during the internship will also help us better understand the content of field practice and help students grow into well-rounded individuals while studying.

The organization of group study of students during the internship is aimed at satisfying the needs and interests of all students during the internship in accordance with the purpose and objectives of basic education. When fieldwork is organized in groups, it reveals the individual characteristics of the students in each subgroup, that is, each subgroup together allows them to expand their potential during the internship.

\section{REFERENCES}

1. Saparov K.A., Haydarova P.B., Yuldasheva M. (2012) Methodical instructions for conducting field practice in invertebrate zoology. (Saparov K.A, Haydarova P.B, Yo'Idasheva M. Umurtqasizlar 
zoologiyasidan o'quv-dala amaliyotini olib borish uchun metodik ko'rsatmalar. 2012 yil.)

2. Dadaev S.D., Mavlonov O.M. (2000) An exemplary program from the field practice of invertebrate zoology. - Tashkent. (Дадаев С.Д., Мавлонов О.М. Умуртқасизлар зоологияси ўқув-дала амалиётидан намунавий дастур. Т. 2000.)

3. Dadaev S., Saparov K. (2019) Textbook of vertebrate zoology by the Ministry of Higher and Secondary Special Education of the Republic of Uzbekistan for universities and pedagogical universities “TURON IQBOL”. - Tashkent. (S.Dadaev, K. Saparov. Umurtqalilar zoologiyasi O'zbekiston Respublikasi oliy va o'rta maxsus ta'lim vazirligi tomonidan, universitet va pedagogika oliy o'quv yurtlari uchun darslik "TURON IQBOL" T:. 2019.)

4. Mavlonov. O., Xurramov. Sh., Eshova H. (2006) Zoology of invertebrates. A textbook for university students. T, National Encyclopedia of Uzbekistan Publishing House: - Tashkent. (Mavlonov. O., Xurramov. Sh., Eshova X. Umurtqasizlar zoologiyasi. Oliy o' quv yurtlari talabalari uchun darslik. T, «O'zbekiston milliy ensiklopediyasi» nashriyoti: T., 2006.)

5. Dadayev S. (2018) Practical training on the subject of invertebrate zoology. A textbook for undergraduate biology students. Navruz Publishing House. Tashkent. (Dadayev S. Umurtqasizlar zoologiyasi o‘quv predmetidan amaliy mashg“ulotlar. Oliy o'quv yurtlarining bakalavriat bosqichi biologiya yo'nalishi talabalari uchun o'quv qo'llanma. "Navro'z" nashryoti. T.2018.)
6. Dadayev S., Saparov K. (2018) Laboratory classes on invertebrate zoology. A textbook for undergraduate biology students. - Tashkent. Navruz. (Dadayev S., Saparov K. Umurtqasizlar zoologiyasidan laboratoriya mashg'ulotlari. Oliy o'quv yurtlarining bakalavriat bosqichi biologiya yo'nalishi talabalari uchun o'quv qo'llanma. T.: “Navro'z”, 2018.)

7. Kulmamatov. A. (2004) Field practice from invertebrate zoology. Study guide. Tashkent. The Teacher. (Qulmamatov. A. Umurtqasiz hayvonlar zoologiyasidan dala amaliyoti. O'quv qo'llanma. T.”O'qituvchi”,2004.)

8. Khamraev A.Sh., and others. (2008) Methodical manual on the table of identification of insect groups. - Urgench. (Хамраев А.Ш. ва бош. Хашаротлар туркумларини аниқлаш жадвали юзасидан услубий қўлланма. Урганч2008.)

9. Dadayev S., Saparov K., Jumanov $M$. (2018) Entomology. A textbook for undergraduate biology students. Namangan. (Dadayev S., Saparov K. Jumanov M Entomologiya. Oliy o'quv yurtlarining bakalavriat bosqichi biologiya yo'nalishi talabalari uchun o'quv qo'llanma. N.: 2018.)

10. Dzidzoeva M. (2009) Pedagogical practice as a condition for the development of students' research competencies. Rastovon-Do. (М.Дзидзоева. Педагогическая практика как условие развития исследовательких компетенций студентов. Растов-на-Дону 2009. г.)

11. Dadayev S. (2016) Parasitology. Textbook for students of pedagogical universities by the Ministry of Higher and Secondary Special Education of the Republic of Uzbekistan. - Tashkent. (S. Dadayev 
Parazitologiya. O‘zbekiston Respublikasi

Oliy va o'rta maxsus ta'lim vazirligi tomonidan pedagogika oliy o 'quv yurtlari talabalari uchun o'quv-qo'llanma. T:.2016.)

12. Dadaev S., Toychiev S., Haydarova P. (2006) Laboratory classes on vertebrate zoology Publishing House of the National Society of Philosophers of Uzbekistan. Tashkent). (Dadaev S., To‘ychiev S., Haydarova P Umurtqalilar zoologiyasidan laboratoriya mashg'ulotlari O'zbekiston faylasuflar milliy jamiyati nashriyoti . T., 2006.)

13. Kashina V.B. (2007) Principles of organizing research activities of bachelors of natural science education in field practice in botany / Izvestiya of the Russian State Pedagogical University named after A.M. Herzen, no. 13 (36): Scientific journal. - SPb. (Кашина В.Б. Принципы организации исследовательской деятельности бакалавров естественнонаучного образования на полевой практике по ботаникеУ/Известия Российского государственного педагогического университета им. АМ. Герцена, № 13 (36): Научный журнал. - СПб, 2007.)

14. Tolipova J.O., Gofurov A.T. (2012) Methods of teaching biology. Textbook for students majoring in biology and protection of human life. - Tashkent. (J.O Tolipova, A.T G'ofurov Biologiya o'qitish metodikasi. Biologiya va inson hayotiy faoliyati muhofazasi ta'lim yo'nalishi talabalari uchun Darslik. T:.2012.) 